\title{
1920년대의『朝鮮公論』사설에 나타난 조선통치론과 내선융화론*
}

최혜주**

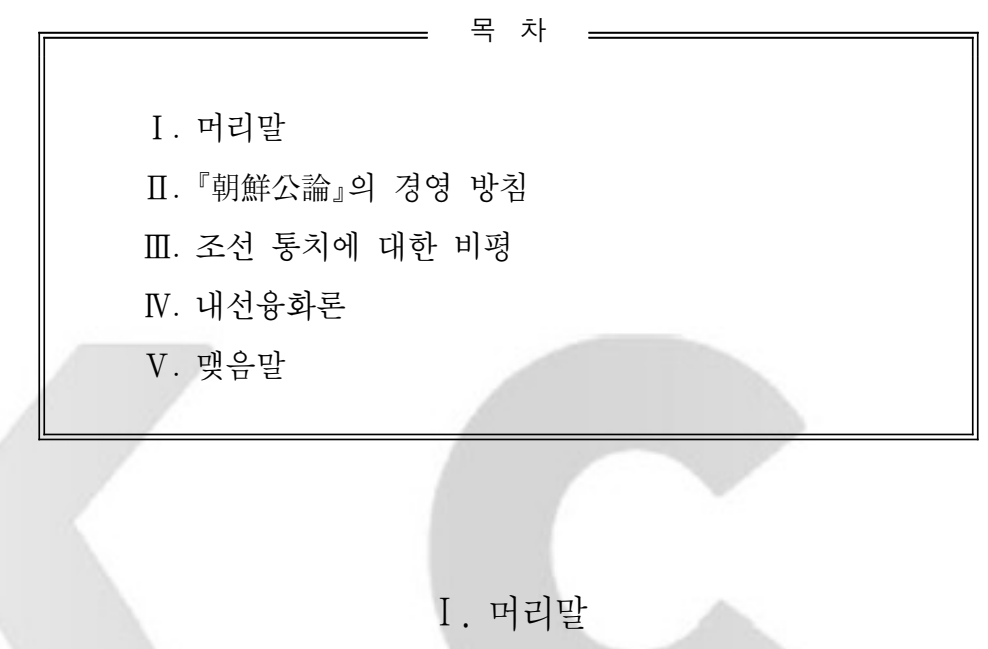

1920년대는 3 - 1 운동을 격은 일제가 1910년대 동화정책의 전략을 문화통치로 바꾼 시기이 다. 동화정책을 유지하면서도 이를 점진적으로 실행하고 차별대우를 완화하려는 것이었다. 그리하여 1920년 대에 들어 '동화'라는 말 대신에 '융화’라는 말이 채용되었다. 또한 1920년 대가 되면 일본에서는 정당정치가 발전하고 정당의 영향력이 식민지 통치기관까지 확대되었 다. 조선총독부는 내각의 간섭을 받게 되어 안정적으로 식민지를 경영하기 어렵게 된 사정 이 있었다. 이 글의 목적은 조선총독부가 직면하고 있던 내외의 통치환경이 악화되는 가운 데 재조일본인이 경영하는 잡지가 1920년대의 식민지 조선을 어떻게 인식했으며 일본의 지 식인들이 조선 문제에 대해 어떠한 주장을 펼쳤는지 살펴보는데 있다.

『朝鮮公論』은 마키야마 고조(牧山耕藏)가 1913년 4월 창간한 이래 몇 차례 사장이 바뀌었 지만 1944년 11월까지 총 380호를 발행한 최장수 월간 종합잡지다. 일제강점기 샤쿠오(釋 尾東邦)가 경성에서 발행한 『朝鮮及滿洲』와 함께 쌍벽을 이루었다.1)『朝鮮公論』은 초대사장 마키야마가 1920년 조선신문사를 매수하면서 당시 편집장이었던 이시모리 히사야(石森久爾) 에게 1925년에 양도되었다. 이시모리는 편집장(1919), 주필(1923), 전무이사(1924)를 거쳐 1933년까지 사장으로 이 잡지를 실제적으로 이끌어간 인물이었다. 그는 경성부회 의원, 경 성방송협회 의원을 역임한 유력 재조일본인이다. 이처럼 사장이 바뀌고 일제의 조선통치 방

\footnotetext{
* 이 논문은 2014년 정부(교육부)의 재원으로 한국연구재단의 지원을 받아 수행된 연 구임(NRF-2014S1A5A2A01013839) ** 한양대학교 비교역사문화연구소 HK교수

1) 최혜주,「잡지『朝鮮及滿洲』에 나타난 조선통치론과 만주인식」, 『한국민족운동사연구』62, 2010.
} 
식이 무단통치에서 문화통치로 바뀌는 변화에 대한 비평과 아울러『朝鮮公論』의 논조와 성 격이 어떻게 변화되는지 살펴보려고 한다.2)

『朝鮮公論』을 검토한 선행연구는 이 잡지의 문예물을 대상으로 분석한 연구가 있고3), 박양 신은 와세다 대학 출신자들의 식민지 조선론을 분석하면서 마키야마의 식민정책론을 일부 소개하였다.4) 김종식은 언론인에서 중의원의원이 된 마키야마의 정치적 정체성의 성장과정 을 『朝鮮公論』기사를 통해 분석하였다.5) 그리고 최혜주는 1910년대의『朝鮮公論』사설에 나 타난 조선통치 담론을 통해 창간 경위와 잡지의 성격을 살펴보고 조선통치의 방향과 비평, 일선동화론 등을 검토하였다.6) 지금까지 본격적으로 연구되지 않은 잡지에 나타난 담론분 석을 통해 기초적 연구를 진행한 것이다.

본고에서는 이러한 연구 성과를 기반으로 『朝鮮公論』이 1920년대의 문화통치를 어떻게 비 평하고 있는지 정치가, 관료, 학자 등 주요 기고자들의 조선통치론과 내선융화론을 중심으 로 검토한다. 첫째, 『朝鮮公論』의 창간 목적과 2 대 사장 이시모리의 경영 방침에 대해 살펴 본다. 둘째, 1910년대의 무단통치와 달리 1920년대 사이토(齋藤實)총독의 통치방침을 어떻 게 평가하고 있는지 검토한다. 셋째, 내선융화를 위한 방법으로 거론된 문제 등을 분석한다. 이를 위해 1920년 1월 통권 94호부터 1930년 12월 통권 213호까지의 공론(언론), 사설, 설림, 주장 등의 기사를 분석하려고 한다.

\section{II.『朝鮮公論』의 경영 방침}

1913년에 창간된 『朝鮮公論』은 총독정치에 공헌하여 식민지 경영과 대륙정책을 확립하고, 모국과 식민지 사이의 정보교환을 위해서 발행되었다. 4 월호의 「발간사」에서는 조선의 실상 을 모국에 알리고 동시에 재조선 일본인을 각성시켜 시정에 도움이 되게 하는 것이 목적이 라고 언급하였다. 이시모리는 초대사장 마키야마 밑에서 기자로서 수년간 근무하였다. 2대 사장이 된 뒤 마키야마와 결별하여 경영방침을 바꾸게 된 최대 이유는 정우본당 소속인 마 키야마의 정당 색깔 때문이었다. 이시모리는 조선을 정쟁의 소용돌이에 넣고 싶지 않다고 단언한다. 조선에서 일본인이 발간하는 『朝鮮公論』의 사명을 무엇이라고 밝히고 있는지 살 펴보자.

그는 『朝鮮公論』이 창간된 이래 10여 년간 이룬 성과로 우사가와 가즈마사(宇佐川一正)초대 총재 시대의 동양척식회사 내부의 문란을 척결한 것, 오오야 곤페이(大屋權本)가 조선총독 부 철도국장관(1910 1917)일 때 철도국의 숙폐를 타파한 것, 한호농공은행의 적폐를 적발 한 것을 들었다. 그리고 데라우치 총독의 비입헌 정치에 반대하는 논진을 펼쳐 3개월 간 발 매금지를 당한 것을 들고 있다.7) 이후『朝鮮公論』이 가져야 할 태도는 총독정치에 대한 비 판적 태도를 견지하면서 정당정파의 관계에서는 “우리는 헌정회도 아니다. 정우회도 아니

2)『朝鮮公論』의 창간 경위와 경영진 구성 및 창간 목적, 잡지의 성격에 대해서는 최혜주, 「잡지 『朝鮮公論』의 1910년대사설에 나타난 조선통치론」, 『한국민족운동사연구』89, 2016.12를 참조.

3) 김청균, 「일본어잡지『朝鮮公論』(1913 1920)의 에세이와 한국인식」『한림일본학』18, 한림대 일본학연구소, 2011: 송미정, 「朝鮮公論』 소재 문학적 텍스트에 관한 연구-재조일본인 및 조선인 작가의 일본어 소설을 중심으로」, 국민대학교 박사논

문, 2009: 조은애, 「1920년대 초반『朝鮮公論』문예란의 재편과 식민의 “조선문단” 구상」, 『일본사상』19, 2010.

4) 박양신, 「사학 와세다 인맥을 통해 본 일본 · 식민지 조선에서의 식민정책론」『아시아문화연구』39, 2015.

5) 김종식, 「1910년대 재조일본인 정치가의 정체성 형성과정」, 『사림』56, 2016.

6) 최혜주, 「잡지 『朝鮮公論』의 1910년대 사설에 나타난 조선통치론」『한국민족운동사연구』89, 2016.12.

7) 石森久爾,「吾人の新たなる使命-本誌の組織變更と吾人の信條, 『朝鮮公論』13권 6호, 1925.6, 2 4叒. 
다. 본당도 아니다. 무색투명, 독립하여 남에게 속박되지 않는 입장에 서서 여론에 역행하는 정치에 대해서는 칼끝을 향해 규탄하는 일에 인색하지 말아야 한다”고 천명하였다. 즉 어느 정파에도 속하지 않는 투명한 언론의 역할을 표명한 것이다.

이시모리는 일본의 정당들이 조선민족에게 바보취급을 당하고 있다고 말한다. "군벌 다나카 (田中義一)를 업은 정우회의 누추함, 재벌·금권에 항복한 이누카이(犬養毅)가 이끄는 혁신 당, 무위무력으로 뿌리가 없고 힘이 없는 본당, 어디에 국민을 지도하고 국민의 負訰에 부 응하는 정당 및 정치가 있는가. 우리는 이러한 정당의 근본박멸을 기하고 새로운 정당의 창 성에 노력하지 않으면 안 된다.”고 주장하였다. 『朝鮮公論』의 태도는 “내지의 용렬하고 추 악한 정쟁을 초월하여 원대 심원한 皇漠를 익찬하여 1 천 7 백만 신부동포의 복지를 증진하 는 일에 노력할 결심”이라고 밝혔다. 전임 사장인 마키야마의 정당 색깔을 문제 삼고 자신 은 정당정파를 초월하여『朝鮮公論』을 경영할 방침을 강조하였다.

이시모리는 계속해서 “우리는 정우본당이라는 것을 싫어한다. 그 정치적 비틀거림은 물론 주의 주장에 대해 서로 용납되지 않는 바가 있는 것을 단언한다. 그런데 마키야마씨는 본당 의 간부이다. 아무리 신문이 민중의 기관이라고 해도 그 사장의 주의 정견과 완전히 다른 논의를 발표할 수 없다.”고 언급하여 마키야마와 결별한 최대 원인이 여기에 있다고 하였 다. 그는 현실적으로 진단할 때 내지의 식량 문제도 중요하지만 조선의 식량 문제는 더욱 중요하며 교육 보급이 막힌 것은 장래 교육 실업자를 양산하는 것이 된다고 우려하였다. 따 라서 조선 문제가 내선융화나 문화정책으로 수습 불가능한 상태가 될지도 모른다고 예상하 였다. 그렇기 때문에 이러한 현상이 도래하는 것을 방지하기 위해서『朝鮮公論』은 “吾人은 어디까지나 신중히 반성하고 筆硯(붓과 벼루)을 새로이 하여 남에게 구속되지 않는 독립의 公議를 가지고 조선민족의 복지증진, 내선 양 민족의 정신적 결합에 혼신의 노력을 다하고 싶다”고 '내선융합'의 역할과 사명을 밝힌 것이다.8)

조선공론사는 이를 위한 상징적 의미로 1926 년 4 월 17 일 신축사옥의 상량식을 거행하여 마키야마가 주재하는 조선신문사와 완전히 결별하였다. 그리고 이후에는 재조선 언론으로서 의 사명을 다하기 위해 적극적으로 중앙에 진출하는 것을 계획하여 1929년에는 동경지국의 대확장을 단행하였다. "종래 독자가 특권계급에 한정되어 서운한 감이 있었던 『조선공론』의 대대적 보급을 기도하는 한편 조선을 위해 필요하고 의의가 있는 여러 사업을 영위한다"고 발표하였다.9)

편집장 호사카(保坂祐玄)는 1942년 1월의 폐간호에서 편집방침에 대해 “당국의 지도방침을 마음에 두고 따르는 것은 물론이지만, 일면에서는 뱃속에서부터 황실중심, 국가본위로 일본 정신 앙양, 對外硬, 국방강화, 공산소멸, 퇴폐문화 배격주의로 일편단심 곁눈질하지 않고 영 리를 전혀 돌보지 않고 잡지를 발행해 왔다”고 밝히고 있다. 『朝鮮公論』은 정치경제 잡지를 표방하면서도 무단통치기에는 민감한 정치문제는 피해가면서 대중적 취향에 맞는 재미있는 기사 위주로 편성했다. 그러나 기본적으로는 황실중심주의, 일본정신주의로 일관하였고 전 시동원체제기에는 국책에 순응해 나갔다.

III. 조선 통치에 대한 비평

8) 石森久爾, 「本社新築と吾人の使命」『朝鮮公論』14권 5호, 1926.5, 2 4쪽.

9) 宮崎義男, 「朝鮮公論の積極的中央進出に就て二內鮮一存一榮の新時代的標語の提唱, 『朝鮮公論』17권 3호, 1929.3, 48 50叕. 
1. 무단통치 평가와 총독권한론

1) $3 \cdot 1$ 운동('소요') 인식과 군비축소

『朝鮮公論』은 1920 년대의 문화정치기에 데라우치의 무단통치를 어떻게 평가했는지 $3 \cdot 1$ 운 동과 헌병제도, 군비축소, 병비충실운동을 중심으로 살펴보자. 오시마 마사노리(大島正德, 동경제대 조교수)는 1919년에 일어난 '소요(3·1운동)'이래 조선인 사이에 유포된 독립사상 이 일본의 국가 문제로서 얼마나 중대한지를 설명한다. 그는 “표면상 매우 순종적이었던 조 선인이 평화회의에서 세계로 퍼진 민족자결주의에 따라 조선 독립사상을 부르짖게 되었 다. 데라우치 총독이 취한 강행적인 동화정책도 정신적으로는 아무런 효과가 없었다”고 무 단통치를 비판하였다. 4 천년의 역사를 갖는 민족을 10 년이나 15 년 만에 성급하게 동화융합 하려고 한 것이 무리였다는 진단이다. 이를 해결할 수 있는 방법은 “조선인도 일본국의 주 권아래 자치생활을 할 수 있도록 독립정신에 만족을 주어야 한다”고 보았다.10) 조선인들이 ‘소요'를 일으킨 원인에 대한 분석은 이와모토 요시후미(岩本善文)가 세 가지로 지적하고 있 다. (1) 선인의 전부가 배일적 사상을 가지고 있는 금일 '선인해방론'은 잘못된 것이다. (2)

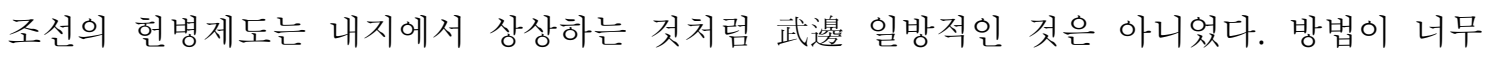
급격하고 자극이 강했다. (3) 학교의 교과서에서 '신국민'에게 병합의 대의를 적절하게 설명 하지 못했다. 즉 학교가 '폭도의 소굴'로 변하여 선민이 광폭하게 나간 것이지 근본적으로 무단통치의 잘못이 아니라는 평가였다. ${ }^{11)}$

'소요'사건에 대한 인식에서 이시모리는 “가장 야만적이고 나쁜 사상이 발효하여 소요사건 이 발발한 것이며, 이 사건으로 조선 통치는 결코 외형적 물질문화만으로 할 수 없고 내면 적 정신문화에 의하지 않으면 성공할 수 없다는 것을 가르쳐 주었다”고 말한다.12) 즉 조선 통치의 성공은 조선민족의 사상이 문화적으로 야마토 민족을 정복할 정도가 되어야만 가능 한 것이라고 인식하였다. 그는 '신조선 건설'이란 “내선민족이 혼화 융합하여 폐하의 적자로 상호 협동, 상호 조화, 상호 존경의 정신에 기초한 새로운 세계를 건조하는 것이 아니면 안 된다”고 말한다.13) 이를 위해서는 사이토 총독의 '마음의 정치', 인격주의를 정치상의 기조 로 삼아야 한다. 역대 총독의 정치 가운데 가장 호감을 주는 것은 사이토의 문화정치이며 지금 통치상 상당한 실적을 올리고 있다고 평가하였다.

데라우치의 무단통치에 대한 평가는 선정이었다고 말할 수는 없지만 후대 사람이 비난할 정 도 악정은 아니었다는 주장도 보인다. 南山太郎은 헌병제도를 옹호하면서 “조선개발을 위해 가장 노력 분투한 것은 데라우치 총독이라고 말하지 않으면 안 된다. 다만 유감은 총독이 독단적이었던 것과 충분한 보좌인이 없었던 것이다. 문제는 헌병경찰제도였지만 당시로서는 당연한 것이었다. 아울러 데라우치 총독이 동화를 고창하면서도 차별대우를 한 것이 바로 선인교육에서 였다”고 차별교육의 문제점을 지적하였다.14)

이러한 '소요' 문제와 함께 불온한 상태를 진정시키기 위한 방안의 하나로 공론화된 것이 군비축소 문제였다. (1) 켄도(研堂迂舅)는 먼저 2개 군단의 내지병을 보내 대연습을 거행한 다. 연습 후 6 개 사단을 두고 연습 상황을 선인에게 보이면 족하다. 조선사단에 필요한 경

10) 大島正德,「內地人の觀たる朝鮮問題，『朝鮮公論』8권 10호, 1920.10, 28 29丝.

11) 岩本善文,「朝鮮騷損側面觀, 『朝鮮公論』8권 11호, 1920.11, 80 84쪽.

12) 石森久彌,「文化政治に對する一考察」, 『朝鮮公論』12권 4호, 1924.4, 4 8叒.

13) 石森久彌,「新朝鮮建設の意義,『朝鮮公論』10권 9호, 1922.9, 4 10驽.

14）南山太郎, 「歷代總督政治の批判,『朝鮮公論』12권 4호, 1924.4, 57 69쪽. 
비는 시베리아출병에 쓴 국비에 비하면 아무 것도 아니다. 헌병제도를 폐지한 것은 대실책 이다.15) (2) 우스이 데츠오(臼井哲夫, 중의원의원)는 모국의 국방선을 조선에 확대시켜야 한 다. 日支露의 제휴, 동양 아세아의 민족적 대동맹을 만들고 시베리아 땅에 완충지대를 만들 어 서구 세력이 진출하는 것을 막아야 한다.16) (3) 니나가와 아라타(蜷川新, 법학박사)는 육 군축소론을 반박한다. 외국인이 일본인을 군국주의의 국민이라고 비평했다고 해서 군비축소 를 해야 하는 것이 아니다. 정당 관계나 반군인 감정에서 군비제한론을 주장해서도 안 된 다. 군비축소론자가 말하는 국가의 교육사업과 생산사업이 중요하지만 군비는 국민의 안태 를 위한 것이다.17) (4) 우에스기 신기치(上杉愼吉, 법학박사)는 군비제한론을 반박한다. 일본 이 세계 일등국이며 5 대 강국의 하나가 된 것은 군비를 갖추었기 때문이다. 이를 축소한다 면 제 2 , 제 3 등으로 떨어질 것이다. 군비편중 보다 교육사업에 힘써야 한다고 주장하는 자가 있지만 아세아를 이끌기 위해서는 경솔하게 군비를 제한해서는 안 된다.18) (5) 미야자키(宮 崎義男)는 조선에 2 개 사단과 진해만의 요항을 갖는데 불과하다면 병사가 너무 적은 것이 다. 내지사단 가운데 국방상 지장이 없는 것을 골라 조선에 옮기자. 상당한 국비가 필요하 지만 다른 문화 시설에 투자하는 비용에 비하면 많은 액수가 아니다. '지나' 시베리아 대륙 을 앞에 두고 유사시에 대비하기 위해 국가적 부담은 어쩔 수 없는 것이다.19) (6) 이시모리 (石森久彌)는 내지에서 1 개 사단만 조선에 이동하자. 그러면 對支출병 등 유사시에 편리하 고 동시에 지방의 경제력을 증가하여 장래 조선에서 육군연습이 있을 경우 경제적 편의가 있을 것이다. ${ }^{20)}$

다만 이시모리의 경우 조선에서의 병비충실운동에 대한 검토를 요구한다. 즉 총독부, 중앙 정부, 참모본부에서 이미 실행하기로 결정이 되었지만 일정한 방침 없이 육군이 선봉이 되 어 추진하고 있다는 것이다. 그는 병비충실을 조선 통치와 연결시킨 것은 시대착오가 심한 것이고 다나카 수상의 영웅주의가 그렇게 만든 것이라고 비판한다. 조선 통치의 근본방침이 무력주의가 아닌 정신주의 정치가 필요하기 때문이라고 말한다. 나아가 조선 통치를 위해서는 사단의 증설이 아니라 減師라도 하는 것이 좋다고 본다. 따라서 내지에만 사단을 설치하지 말 고 1 개 사단 정도를 조선에 이동하여 對支출병시에 대비하자. 아울러 경비를 위한 것이라면 국경에만 헌병제도로 바꾸는 것이 필요하다고 주장하였다.21) 병비충실 운동과 관련하여 미 야자키는 국경의 불안을 증병의 논거로 삼는다면 그것은 국경 방비에만 그쳐야 하며 조선 전체의 병비 충실의 구실이 될 수는 없다고 말한다. 조선에서 병비를 충실해 해야 하는 이 유는 남북만주에서 일본의 특수한 이익을 확실히 획득하기 위한 것이어야 한다. 단지 지방 의 번영을 촉진하기 위한 문제가 아니라 만주의 위험을 예상하여 '지나' 내지의 국정의 향 방과 관련한 국책상의 급무이기 때문이라고 보았다.22)

이처럼 무단통치 평가에 대해서『朝鮮公論』은 $3 \cdot 1$ 운동 이후 독립사상의 유포가 큰 문제이 며 가장 큰 문제는 헌병제도 폐지였다고 본다. 헌병제도 폐지에 대한 논란은 문화정치기에 도 계속되었다. 사이토(齋藤繼述)는 식민지에서 위력적 경찰이 필요하므로 헌병 증가가 필 요하다고 주장하였다.23) '헌병제도 폐지는 대실책'(研堂迂帠), '헌병제도는 당연하다'(南山太

15)研堂迂叟、「治鮮管見山、『朝鮮公論』8권 11호, 1920.11, 57 58驽.

16) 白井哲夫, 「我國防輪廓の擴大, 『朝鮮公論』8권 11호, 1920.11, 32 34쪽.

17) 蛈川新,「陸軍縮小論を駁す」、『朝鮮公論』9권 7호, 1921.7,9 10叒.

18) 上杉愼吉,「軍備制限論を排す」,『朝鮮公論』9권 9호, 1921.9, 8쪽.

19) 宮崎義男,「朝鮮の軍供掂長要望運動, 『朝鮮公論』16권 5 호, 1928.5, 27 28쪽.

20) 石森久彌,「朝鮮兵備充實の本體武力主義力精神主義加, 『朝鮮公論』16권 7호, 1928.7, 2 5 5 空.

21) 상동

22) 宮崎義男,「兵備充賽と鮮滿の提携朝鮮兵備充賽運動の指導者に呈す,『朝鮮公論』16권 7호, 1928.7, 89 90票. 
郎), ‘국경에만 헌병제도를 실시하자'(石森久彌)는 주장들이 제기되었다. 대체로 군비축소를 반대하는 주장이 대세를 이루지만 교육사업에 대한 투자가 시급하므로 군비를 축소해야 한 다는 주장도 있었다.

\section{2) 문관 총독과 척식성 설치}

데라우치 총독에 대한 비판과 함께 문관 총독, 총독의 권한, 총독 정년제 문제가 논의되었 다. 먼저 이시모리는 문화통치기의 사이토 총독 평가에 대해 상당히 호의적이어서 조선총독 으로서는 가장 적당한 인물이라고 보았다. 만일 사이토가 중앙정부에 입각할 가능성이 있다 면 이제는 문관 총독이라도 지장이 없는 시대가 되었다고 언급하였다. 그러나 사이토 대신 에 다나카(田中義一) 육군대장이 조선총독이 된다면 조선인의 반감이 극도에 달해 데라우치 시대의 후기 사조를 재현하는 반발이 일어날 것이라고 반대하였다. 그만큼 조선인을 통치하 기 위해서는 이전의 통치방식인 무단 억압통치로는 좋은 결과를 가져올 수 없다는 판단이었 다.

소위 내선융화의 사상을 가지고 있지 않다. 힘의 압복에 대해 힘을 가지고 저항하려고 하는 생각을 하고 있지 않다. 어떻게 해서든 문화적으로 내지인보다도 우월한 지위를 얻을 수 있을까. 이것이조선민족의 진정이다. 이러한 사조가 팽배하고 있는 금일 만일 거기에 무력본위의 정치를 펼친다면 어떻게 될 것인가. 평화로운 양 의 무리에 사나운 狼을 던진 것과 같다. 조선이 문관총독 시대이고 무관총독의 시대가 지나갔다는 것은 이 점 에서 분명하다. ${ }^{24)}$

그러면서 문관 총독이 될 만한 사람으로 고토 신페이(後藤新本), 노다 우타로(野田卯太郎), 덴 켄지로(田健治郎), 미즈노 렌타로(水野鍊太郎), 시모오카 추지(下岡忠治)를 지목하고 있 다. 이 가운데서 시모오카 정무총감이 도량, 노회, 수완, 재간, 식견에서 탁월하다고 평가하 였다. 이와 비슷한 주장은 군벌정치의 재현을 경계하는 논설에서도 보이고 있다. 다나카 내 각이 성립되면서 사이토총독이 3 국 군축회의 참석을 위해 조선을 6 개월간 비우는 일이 발 생하였다. 이에 우가키대장이 총독대리로 부임하게 되자 “만일 우가키대장이 총독에 취임하 여 무단정치를 재현하게 된다면 통치의 혼란을 가져올 것”25)이라고 지적하면서, 총독이 6 개월 이상 자리를 비우고 대리를 두는 것은 무책임한 일이라고 비판하였다.26) 이시모리는 군축회의가 결렬된 뒤 사이토가 돌아왔으나 그의 거취를 두고 논란이 일어나는 것에 대해 “사이토는 독립 소요사건 이후 조선통치의 난문제를 해결한 명총독”이라며 그의 치적으로 치안유지, 교육의 보급개선, 산업개발, 교통위생의 정비, 지방제도의 개혁을 지적하였다.27) 다음 총독의 권한과 관련하여 제기된 식민지 감독기관이라고 할 수 있는 척식성의 설치에 대해서 살펴보면 먼저 1910년 일본정부는 조선을 내무성 소관으로 하는 것이 무리라고 생 각하여 내각 총리대신 산하에 척식국을 설치하였다. 그러나 1912년 야마모토 내각의 행정 정리 정책에 따라 척식국을 폐지하고 대만과 가라후토, 조선이 내무성 관할로 바뀌었다. 이에 마키야마는 척식성을 설치할 것을 제안하였다.28) 그러나 1918년에 설치된 데라우치 내각은 기

23) 齋藤繼述,「警察行政上より見たる憲兵』、朝鮮公論』10권 1호, 1922.1, 16 17昰.

24) 石森久彌、「齋藤男の內府入實現を前提として朝鮮に於ける文官總督の可否を論ず」『朝鮮公論』13권 2호, 1925.2, 2 6票.

25)「軍閥政治の再現を戒む」,『朝鮮公論』15권 5호, 1927.5, 5 7쪽.

26) 石森久爾,「宇垣總督代理を迎へて」, 『朝鮮公論』15권 6호, 1927.6, 2 5 空.

27) 石森久彌, 「齋藤總督の歸朝と去就, 『朝鮮公論』15권 9호, 1927.9, 4쪼.

28) 牧山耕藏,「植民地監督機關論, 『朝鮮公論』1권 6호, 1913.9, 3 4 骂. 
존의 척식국을 다시 부활시켜 제반 사무를 관장하게 하였다. 마키야마의 척식성 설치 주장은 이때 실현되지 않았다. 그는 단순히 식민지 행정을 위해서가 아니라 제국들의 이해관계에 따 라 척식성을 설치하는 것이 긴요하다고 주장하였다.29) 결국 1927년 다나카내각에 의해 척식 성설치준비위원회가 설치되고 1929년 척무성이 설립되었다.30)

이러한 부침과정을 겪으면서 자리 잡은 척식성은 내각이 식민지 통치를 철저하게 관리하기 위한 시도에서 이루어진 것이었다. 척식성의 역할은 식민지와 내각의 사다리가 되어 척식사 업을 보호하고 이주식민을 지도관장하는 데 있다. 그러나 식민지를 실제 통치하는데 중요한 역할을 하는 것은 조선총독을 비롯한 각 식민지의 장관이라고 할 수 있다. 이시모리는 척식 성의 신설을 기회로 조선총독이 갖는 제령권과 대만총독이 갖는 율령권을 폐지하자는 의논 은 아직 참정권을 갖지 않는 지역에서 실시하는 것이 곤란하다고 보았다. 그러나 조선 통치 에서 총독과 척식대신의 권한을 어떻게 할 것인지의 문제가 드러나게 되었다. 조선총독과 척식대신을 겸직시키자는 의견과 총독의 권한을 축소해야 한다는 주장이 제기되었다. 이에 대해『朝鮮公論』에서는 정무의 성질을 혼동시키는 오류라고 보았다. ${ }^{31)}$

이시모리는 자신은 “내지연장론자이고 척식성 설치 촉진론자”라고 밝히며 조선에서 척식성 설치를 둘러싸고 파란이 일어나고 있다고 말한다. 친일 단체인 동민회와 갑자구락부에서 현 내각의 척식성 설치가 조선을 남양이나 가라후토와 동일 취급하는 처사라는 비판을 소개하 였다. 즉 척식성 설치에 따라 조선총독의 지위가 저하되는 것에 대한 우려였다. 그는 조선 을 진정한 내지연장으로 만들자고 주장한다. 이를 위해 조선의 모든 자격을 내지와 같게 하 고 권리와 의무를 통일하여 균등하게 하는 것이 필요하다고 본다. 조선을 북해도나 아오모 리현과 동일화 하는 것이다. 조선에서 조선총독과 정무총감을 폐지하여 재조선 내선인에게 내지와 같은 참정권을 부여하고 모든 문제를 내지와 통일하여 병역의무도 부여하는 것이다. 이렇게 해서 진정한 내지연장, 조선개발이 이루어지면 내선 양 민족의 혼일융화가 가능해질 것이라고 주장하였다. ${ }^{32)}$

그리고 척식성 신설 파문에 대해서는 추밀원에서 척식성 아래 조선총독부를 두고 조선총독 의 지위를 척식대신에 속하게 하는 관제에 대해 반대하고, 동민회와 국민협회가 반발한 것 을 소개하고 있다.33) 특히 추밀원의 고문관 사이토자작이 조선총독을 지낸 인물로 조선통치 에 이해를 갖는 입장에서 반대한 것이 조선민중에게 일대 파동을 야기시켰다고 지적한다. 동민회의 중견분자들이 동민회를 탈퇴하고, 국민협회도 “4천년 역사와 문화를 갖는 조선을 남양의 토인과 동일시하는 것을 참을 수 없다는 비장한 결심을 가지고 머지않아 해산을 단 행하고 회원으로 하여금 자유행동으로 나가도록 한 것”이라고 보았다.

마지막으로 미야자키(宮崎義男)는 조선을 정쟁권 밖에 두기 위해서는 총독정년제 제정을 제 창하였다. 총독의 정년 제정이 관직의 위신을 가볍게 하는 것이라는 의논이 있지만 정국의 분규에 동반하여 총독의 진퇴에 관한 억측이 나오는 것이야말로 그 위신을 크게 손상시킨다 고 보았다. 조선통치의 성패는 일본의 국운에 지대한 관계를 가지기 때문에 조선통치를 위 해 필요한 것이라는 주장이다.34)

이상에서 살펴본 것처럼 데라우치 총독에 대한 비판과 함께 문관 총독이 필요한 시대가 되

29)牧山耕藏,「帝國凹圍の情勢に鑑みて拓殖省を設置せよ, 『朝鮮公論』14권 9호, 1926.9, 17 8 8쪼.

30) 기유정, 「식민지 조선에 대한 척식성 지배 논란과 그 함의」, ${ }^{\circledR}$ 정치사상연구』19-1, 2013 봄.

31)「總督權艮論の誤謬」『朝鮮公論』15권 10호, 1927.10, 7-9쪽.

32) 石森久彌,「队地延長の本質的意義=朝鮮總督廢止論」『朝鮮公論』17권 5호, 1929.5, 2 3쪽.

33)「拓殖省新設か投げた波紋-同民會の態度」『朝鮮公論』17권 5호, 1929.5, 38丝.

34) 宮崎義男,「(朝鮮を政爭港外に置くため)總督停年制制定を提唱す」『朝鮮公論』16권 4호, 1928.4, 29 30驽. 
었다는 견해와 시모오카 정무총감이 그 적임자라는 주장도 보인다. 그러면서 다시 군벌정치 의 재현을 경계하고 있다. 총독의 권한과 관련하여 척식성 설치에 따라 조선총독의 권한이 저하되는 것에 대한 논의가 나오고 있다. 그리고 조선을 정쟁권 밖에 두기 위해서라면 총독 정년제가 필요하다는 주장도 제기되었다.

\section{2. 조선자치와 참정권}

1920년대의 조선 통치에서 대두되는 중요한 문제 가운데 하나는 조선인에게 정치참여를 허 락하는 여부였다. 이것은 조선총독부의 공식적 입장인 내지연장주의론과 일본정부와 조선총 독부에서 비판적인 조선자치론으로 나누어진다. 조선인에게 참정권을 부여하는 문제를 중심 으로 어떠한 담론이 등장하는가를 살펴보자.

먼저 수임은 특별조선의회를 설치할 것을 주장한다. 참정권운동이란 일본제국의회에 가서 중의원의원이 되게 하는 것인데 이것이 과연 효과가 있을지는 의문이라고 말한다. 시기상조 이므로 우선 조선에서는 조선인이 조직한 조선의회를 건설해야 한다는 것이다.35) 이러한 제 안은 쫏랄외의 주장에도 보인다. 즉 그는 참정권운동은 조선의회를 요구한 것이 아닐 것이 라고 말한다. 조선인들은 '내선일가'의 취급을 바라고 행정제도의 근본적인 개폐를 요구하는 것이다. 조선 대표자가 제국의회에 하나의 교섭단체를 만들고 국정을 의논하는 것은 바람직 하지 않다. 조선을 하나의 지방으로 취급하는 것도 경제상으로 인정할 수 없는 일이라고 지적 한다. 조선에서 대신이 나와 국민이 모두 승복하는 날까지는 완전히 조선은 별개의 정치지 역으로 특별의회를 두는 것이 내선 상호의 행복이 될 것이다. 따라서 조선의회는 하나의 완 충지대이며 지방자치부터 추진하는 것이 타당하고 참정권을 주면 독립운동은 자연히 잊어버 릴 것이라고 보았다. 36$)$

다음 시모무라 히로시(下村宏, 법학박사)는 내지연장이 옳은지, 참정의 방법은 어떻게 해야 하는지에 대한 시비는 상당히 복잡하다고 말한다. 그는 대만의회 설치청원운동은 수년 간 계속되고 있지만 조선의회 설치청원운동이 없는 것은 중대한 문제라고 인식하였다. 더 이상 지체되어서는 안 되며 참정권을 논할 때 병역문제를 고려하지 않는 것은 이해하기 어렵다고 말한다. ${ }^{37)}$ 이에 대해 국민협회 총무 金丸은 다음과 같이 반박한다.

\footnotetext{
조선의회 설치의 청원운동이 없었던 것을 중대 문제라고 말하는 박사의 소견은 조선의 민중은 제국의 주권 하에서 자치하는 것을 바라지 않고 독립운동에 열중하는 자가 많았기 때문에 조선의회설치의 청원운동이 없는 것이라고 생각하여 이를 우려한 것이 아니겠는가...그런데 우리의 운동이 미약하여 박사의 기억에 남 아있지 않아조선민중의 참정권 획득운동에 관하여 말하는 게 없었던 것은 우리가 부끄러워 견딜 수 없는 것 이다. 금후는 우리의 운동이 적어도 유력하게 되어 박사처럼 우리 동지의 주장과 동일한 의견을 갖는 인사들 에게 철저하게 선전되어 다대한 원조를 받을 수 있도록 기하려고 한다.38)
}

조선민족의 참정권 요구를 어떻게 인식할 것인가와 관련하여 이시모리는 제국의회에 대하여 조선인이 분개하고 개조를 외치는 것이 일본에 대한 애착을 가진 증거라고 말한다. 조선의 민심이 완전히 떠나서 가장 위험한 시기에 직면하지 않도록 제국의회는 각성해야 할 것이라

35) 金心石,「朝鮮總督と參政權」『朝鮮公論』11권 3호, 1923.3,37驽.

36) 翠郎生,「朝鮮と參政權」『朝鮮公論』12권 6호, 1924.6, 30 32空.

37) 下村宏,「朝鮮臺灣統治對策』,『朝鮮公㖮』14권 4호, 1926.4, 11 12驽.

38) 金丸,「下村博士の鮮臺統治策を讀む一朝鮮の參政權問題に就て」、朝鮮公論』14권 5호, 1926. 5, 10 11叒. 
고 촉구하고 있다.39) 그러면서 그는 조선인을 이국인 취급하지 말라고 호소하면서 참정권 문제에 대해, “중앙정부만이 아니라 모국민이 조선을 등한시하여 $\cdots$ 이국시하고 있는 유식자 가 많은 것은 금일 시작된 일이 아니지만 금일에 이르러도 여전히 그 완미한 사상을 가지고 있는 것은 개탄하지 않을 수 없다.”40)고 지적한다. 이러한 모국인의 각성을 촉구하는 인식 에 대해 이노우에 가쿠고로(井上角五郎)는 내선융화를 위해서는 조선주민의 참정 권리를 부 여해야 한다고 다음과 같이 언급한다.

다만조선의 주민에게 참정의 권리를 부여하지 않는 한 내선융화의 실은 마침내 완전할 수 없다고 믿는다. 아 국은 이미 보선의 제도를 정하고 그 실시도 멀지않은 이즈음에 조선의 귀족이나다액납세자가 그 대표를 귀 족원에 출석시킬 자격이 없는 것을 당연하다고 할 수 있을까. 조선주민의 가령 제한선거에도 완전히 그 대표 를 중의원에 출석시킬 자격이 없는 것을 당연하다고 할 수 있을까. 만약 조선의 주민을 대만 화태의 주민과 동일시하여 그 과거의 역사를 무시하고 그 현재의 문화를 무시한다면 이것은 조선의 주민을 모욕하는 것이 심한 것으로 내선융화의 실을 올리지 못하는 것은 당연한 결과라고 말하지 않을 수 없다.41)

한편 치바 료(千葉了)는 참정권 문제를 해결하기 위한 방안 하나는 조선의회 설립을 통해 해결해야 한다는 것이다. 이 전제로 지방자치제도 실시를 실현할 시기가 왔으며 중추원의 제도개정이 구체적으로 추진되어야 한다. 다른 하나는 참정권 문제와 동시에 징병제 실시를 착수해야 한다고 지적하였다.42) 그러나 이것이 이상론에 지나치다는 미야자키(宮崎義男)의 주장을 살펴보자. 그는 조선에서 내지연장주의의 자의를 방패로 중의원선거법 시행을 요구 하는 것은 결코 합리적이 아니라고 보았다. "조선에 중의원의원 선거법을 시행하는 것은 특 수 법역인 조선을 내지와 混一해서 취급하는 것이고, 일방에서 조선총독부를 폐하여 지방청 만을 두고 일체의 행정은 중앙정부에서 통할하여 사법제도도 근본적으로 고치지 않으면 불 합리하게 된다.”고 하여 중의원선거법을 조선에 시행하라고 주장하는 것은 잘못된 것이라고 비판하였다.43) 그는 이러한 이상론은 적절하지 않으며 조선의 역사, 전통, 민족성을 고려하 지 않은 것이라고 단언한다. 내지연장주의의 실현이라는 것이 내선융화, 혹은 동화와 동의 어인데, 이 참정권은 조선인이 운용하는 것이 아니면 안 된다고 주장한다. 즉 풍속, 습관을 달리하는 조선인 대표자를 제국의회에 참석시키는 것은 무의미한 일이 된다. 조선인에게 참 정권을 부여하는 진정한 형식은 조선의 민중이 조선 통치에 참획하는 것이며, 이것은 중추 원제도를 개선하여 실제적으로 민의창달의 기관으로 만드는 것이 필요하다고 지적하였다. 그는 “중추원은 거의 '공허한 기관'이지만 이를 쇄신하여 그 존재의 사명을 달성시키는 것 이 필요하고 그것이 참정권 부여의 전제적 조건이 아니겠는가”고 언급하여 중추원 개선을 통해 조선인에게 참정권을 부여하는 것이 중요하며 막연히 중의원선거법 시행을 요망할 것 이 아니라는 주장이다.44)

1925년 11월 경성일보 사장 소에지마 미치마사(副島道正)가 총독부 기관지인 경성일보에「 총독정치의 근본의」라는 글을 통해 자치론을 제창하였다. 사이토는 여전히 '내지연장주의'를 고수하고 있다고 답했다. 경성일보는 사설을 통해 소에지마의 글은 총독부측의 주장과 관계 가 없다고 하면서도 다시 조선자치론은 조선을 영원히 통치하기 위해 가장 타당한 통치방식

39) 石森久爾, 「議會の醜態を朝鮮民族は如何に見る乎」『朝鮮公論』14권 4호, 1926.4, 2 4票.

40) 石森久彌,「母國民上朝鮮を異國視する勿れ』、朝鮮公論』14권 7호, 1926.7, 2 3쪽.

41) 井上角五郎, 「朝鮮住民と參政の權利, 『朝鮮公論』15권 4호, 1927.4, 25 쪽.

42) 千葉了, 「朝鮮問題の實狀, 『朝鮮公論』15권 4호, 1927.4,35 36쪽.

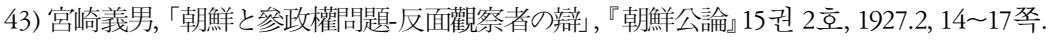

44) 宮崎義男,「中樞院改善論」『朝鮮公論』15권 12호, 1927. 12, 28 30쪼. 
이라고 주장했다. 이에 대해 이시모리는 “전 경성일보사장 副島伯 등은 당시 발작적으로 조 선의 자치제 등을 고조시켜 조선자치에 대해 깊이 집착하여 강조하고 사이토 총독도 이에 대해 상관하지 않는 태도를 취한 것은 기괴한 것이다. 통치의 근본대책을 흔드는 것이라고 하지 않을 수 없다.”고 비판하였다. 이어서 “실제 정치에 소홀한 학자의 대부분은 영불의 식민지통치에서 실패한 예를 들어 내지연장주의를 배척하고 식민지에 대한 특수한 참정권의 설정을 바라는 자가 있지만 이것도 탁상공론, 조선은 4 천년 역사와 2 천만 민중을 갖는다. 세계 각국에 이와 같은 특수한 사정에 놓인 식민지는 없다. 우리는 한갓 발작적, 僞學的, 현 학적 書生論에는 찬성할 수 없다.”고 지적하여 조선 통치는 내선일체, 내지연장, 내선인 혼 일 융합주의로 나가야 한다고 역설하였다. ${ }^{45)}$ 이시모리는 여기서 한 걸음 더 나아가 조선 통 치의 근본방침은 '조국연장주의'로 가지 않으면 안 된다고 말한다. 그가 말하는 '조국연장주 의'는 ‘내선일체’에서 '만선일체’로 확장시키는 것을 의미한다. “일청·일러 兩役은 조선을 중심으로 한 것이었고 정치상, 경제상, 군사상의 제 문제에서 인구, 식민의 제 문제에 이르 는 모든 것이 조선 중심주의지만, 昭和維新의 금일에 이들 제 문제의 기조이고, 중심은 滿 ㅁㅜㅜ”이라고 지적하였다. 즉 이시모리는 일본의 연장으로서의 조선에 그치지 않고 조선을 발 판으로 만주에 진출하여 만주와 조선을 하나로 하는 대륙정책을 추진할 필요성을 제기한 것 이다.46)

쫏랄ㄴㄴ은 지방자치가 조선 통치상에 좋지 않은 영향을 끼친다고 생각지 않는다는 전제하에 신속하게 지방자치를 실시하고 그 실적을 보고 참정권을 부여할 것을 고려하자는 의견을 제 시하고 있다.47) 그러나 조선을 독립시킨다고 하는 전제가 아니라면 자치제는 크게 논의할 성질이 아니라고 하여 자치제 논의를 반대한다. 그 이유는 (1) 조선은 다른 식민지와 달리 일시동인의 나라이며 제국의 일부이다, (2) 실제 정치와 식민정책론은 다르다, (3) 조선의 지 세는 '지나', 러시아와 접양지이다, (4) 조선 주민의 문화정도가 모국민과 비교하여 훨씬 미 치지 못한다. 자치제를 실시하면 소수의 내지인을 압박하거나 도리어 모국과 조선사이의 평 화를 해칠 수 있다는 것이다. 아울러 조선에서의 참정권 문제는 조선인만의 문제가 아니라 조선에 있는 내지인과의 공동 문제라는 인식도 보인다.48)

이상에서 살펴본 것처럼 조선인에게 참정권을 부여하는 문제가 논란이 되었다. 金心石과 쫏 郎生은 조선에 특별의회를 설치하고 지방자치를 실시하여 참정권을 주면 독립운동을 잊게 만드는 방법이 될 것이라고 보았다. 이노우에는 내선융화를 위해서는 조선인에게 참정권을 부여해야 한다고 말하고, 치바도 참정권 문제와 함께 징병제 실시를 제안하였다. 그러나 미 야자키는 참정권론은 이상론에 불과하며 조선에 중의원선거법을 시행하는 것보다는 중추원 제도의 개선이 필요하다고 하였다. 이시모리도 조선 통치의 근본방침은 내지연장주의에서 ‘조국연장주의’로 가지 않으면 안 되며 만선일체론에 의해 문제를 해결할 것을 촉구하였다.

\section{IV. 내선융화론}

1. 조선청년의 사상 선도와 민족성 연구

45)石森久彌,「昭和維新と朝鮮統治一山梨總督の清鑒に供す」,『朝鮮公論』16권 1호, 1928.1, 5 6叒.

46) 石森久彌,「朝鮮經營の根幹」『朝鮮公論』16권 2호, 1928.2, 3 4쪽.

47) 翠郎生,「地方自治創始の時機至る」、『朝鮮公論』16권 4호, 1928.4, 31 32丝,

48）公論子, 「副島伯の朝鮮統治の現在及將來を讀みてこれに贊意を表せず」, 『朝鮮公論』16권 6호, 1928.6, 27〜30骂. 
일제는 조선을 식민지로 영유한 직후부터 조선인의 완전한 일본인화에 큰 비중을 두고 식민 지 정책을 전개시켜 나갔다. 이러한 원칙은 1920년 하라(原敬) 수상이 <朝鮮問題私見〉을 통해 식민통치의 원칙으로 동화주의, 즉 내지연장주의를 내세우면서 공식화하였다.49) 이러 한 동화주의에 입각한 식민통치는 우가키 가즈시게(宇垣一成) 총독 시기의 '내선융화'를 거 쳐 1937년 중일전쟁을 전후하여 ‘내선일체’론이 대두하면서 모든 식민정책은 조선의 민족과 문화를 말살하는데 집중되었다. 1920년대의 내선융화로서 동화의 주요대상은 중상류층 또 는 지식인 계급이었다. 이하 내선융화론에 관한 담론에 대해 조선청년의 선도와 민족성 연 구, 내선융화론의 방법을 중심으로 살펴보자.

히라누마 요시로(本沼淑郎)는 조선인 교육에 대해 주의할 점으로 역사, 국어, 수신교육을 들 고 있다. (1) 역사교육은 정신교육상 중대한 영향을 미치고 있는데, 학교에서 조선인에게 가 르치는 역사교육과 가정에 전해지고 있는 역사가 모순되고 있다. 이를 바로잡기 위해 진정 한 역사편찬이 필요하다. (2) 국어는 국민성, 통치상에서 큰 영향을 미친다. 종래 구라파의 문명국은 식민지 인민을 국어를 가지고 정복하였다. 내지어를 철저하게 하는 것이 필요하지 만 초보교육은 조선어로 하는 것이 좋다. (3) 조선에는 유교가 유행하므로 '誠'을 가지고 조 선인 교육의 근본의를 삼는 것이 좋다. 조선인에게 우리 황실에 충성하고 국가를 사랑하도 록 가르치는 것은 어렵다. 그러나 차별적 대우를 철폐하여 그들의 자각을 기다리는 것이 필 요하다고 보았다.50) 조선인을 교육하는데 있어 ‘국어'로 하느냐 '조선어’로 하느냐는 큰 논 란이 되었다. 國井泉는 조선인은 무차별적 취급을 요구하면서도 교수어에 대해서는 '조선어' 로 가르쳐야 한다는 차별적 요구를 하는 모순을 가지고 있다고 비판적으로 보고 있다.51) 이 러한 차별교육의 문제에 대해서는 金義用의 기고문에서 야마토민족도 조선민족도 타이완민 족도 오키나와나 쓰시마 카라후토 치시마의 住族도 같은 제국 신민이기 때문에, 그 사이에 어떠한 차별도 있을 수 없다. 각 민족 사이에 있는 軒輕을 가지고 이를 무시하는 것은 "일 시동인의 聖旨도 閑却되는 것”이라고 비판하였다.52)

大廷儀三郎(함흥고등보통학교장)은 '문화정치' 아래, 차별철폐, 일선융화를 말하고 있지만 진 정한 융합제휴를 위해서는 일선인의 공학이 중요하다고 보았다. 공학은 초등교육부터 하는 것이 가장 좋지만 용어의 불편 등이 있어 중등교육부터 하는 것이 좋을 것이라고 한다. 공 학을 하면 국민성을 몰각하게 될 것이라고 우려하는 사람도 있으나 이것은 "봉건시대의 쇄 국주의의 꿈을 반복하는 것으로 다이쇼의 대국민적 襟度를 모르는 癡言” 이라고 평하였다. 공학으로 융합된 조선인이 각 방면에서 활약하게 되면 차별하려고 해도 할 수 없게 될 것이 라고 주장하였다. ${ }^{53)}$

가다 나오지(賀田直治, 西鮮식산철도회사 상무)는 문화통치기에 있어서 교육의 문제를 산업 개발과 관련지어 중요하게 인식하였다. 그는 내지와 조선이 연관적으로 산업방침을 실행하 는 데는 급속하고 견실하게 이루어져 하며, 조선 개발의 문제는 일본제국의 사명을 다하는 거국일치적인 중대 문제라고 말한다. 지금 “조선의 근본은 산업에 있고 이것에 따라 의식주 와 사상이 안정되어 교육비를 지출할 수 있게 되고 교육에 의해 더욱 산업의 기초를 배양할 수 있기 때문에 산업과 교육은 협조하지 않으면 안 된다.”고 지적하여 조선의 가장 중요한 요무라고 보았다.54)

49)山本有造,「日本における植民地統治思想の展開」『アジア經濟』32-2, 1991, 37䂬. 50) 平沼淑郎, 「鮮人敎育の根本」『朝鮮公論』9권 6호, 1921.6, 43 48쪽.

51) 國井泉,「先覺者と稱する朝鮮人に與子、『朝鮮公論』9권 6호, 1921.6, 105 108驽.

52) 金義用, 「現代敎育の理想と朝鮮人㸚育問題, 『朝鮮公論』9권 7호, 1921.7, 73 74叒.

53) 大廷儀三郎, 「日鮮融和と共學」『朝鮮公論』11권 10호, 1923.10, 146쪽. 
조선공론 기자는 내선융합을 기하는데 필요한 주요조건으로 학술 주입교육을 고쳐 인격 양 성교육에 중점을 두고, 사회교화 시설을 확충하여 문교를 일으키고 사상 선도를 도모하는 것이라고 하였다.55) 이시모리는 근본적으로 중요한 것은 '사상'의 문제이고 조선인의 사상 이 점차 근육노동이나 농업에 대한 혐오 현상이 나타나는데도 학무당국자는 여전히 졸업생 과 학생수의 증가에만 만족하고 있다는 것이다. "학교교육이 고등유민을 만들고 그것이 나 아가 소위 不良선인으로 바뀌는 것은 무서운 것이다. 학무당국자는 실무와 노동을 피하려고 하는 조선인의 결점과 단점을 어떻게 교정할 것인가. 이 문제가 정당하게 해결되지 않으면 장래의 정치에 큰 영향을 미칠 것”이라는 우려를 나타냈다.56) 나아가 조선은 경제적 압박 때문에 사상악화가 일어나는 우려할 만한 상태가 될 것이라고 보고 있다. 이것은 일본 내의 사상 악화보다 무서운 상태가 될 것이라고 예상하고 있다. 경제적 부담이 늘어날수록 민족 투쟁이라는 사상적 배경도 작용하여 무서운 소용돌이를 일으킬 것이므로 당로자들은 심각하 게 대처할 것을 주문하였다. 이를 막기 위해서는 조선 청년들에게 문학교육 보다 쌀을 많이 생산하는 법, 감자를 만드는 법을 가르치고, 농촌교육의 필요, 실업교육의 보급이 가장 시급 한 문제임을 각성시키는 교육방침으로 바꿔야 한다고 보았다. 조선민족이 영원히 살 수 있 는 길은 농촌경제의 향상과 생산증가의 목적을 달성하여 경제본위, 산업본위와 함께 교육의 대방침을 수립하는 일이라고 주장하였다.57)

河野節夫(충남 사무관)는 내선융화의 일환으로 조선에서의 교육과 함께 청년회 설립을 통한 민심선도의 필요성을 주장하였다. 현재 68 개 단체 1 만 여명의 회원을 망라한 조선청년연합 회가 조성되었는데, 이들 청년들이 국가의 통치를 잘 이해하여 시정에 적응하는 행동에 나 선다면 바람직한 일이 될 것이라고 말한다. 그러나 청년회의 활동은 우려할 만하며 청년회 를 개조하여 민심선도의 보조기관이 되게 하는 것이 바람직하다고 보았다. 이를 위해 먼저 청년회와 같은 민족적 차별적 색채를 없애고 내선인 공립의 민의창달 지방개량기관을 만들 어야 한다. 그리고 민심선도의 기관을 지방관리 및 학교교원이 지도하게 한다면 청년들의 정치적 불안을 제거할 수 있고 그들을 교화할 수 있는 기회를 만드는 방법이 된다고 언급하 였다. 이러한 민심지도 기관에 의해 내선융화는 가능하게 될 것이라고 전망하였다.58) 아울 러 내선융화를 위한 방법은 민족의 반감을 초래하지 않는 일이라고 보았다. "내지인이 내지 문화를 가지고 조선 문화를 대신하려고 한다면 이는 융화를 방해하는 일이 된다” 고 말한다. 이를 위해서는 공동으로 대문화를 건설할 수 있도록 공동 사명을 갖는 것이 중요하며 지금 완전한 동화가 어렵더라도 점차 '융화혼일'에 나아가려는 노력이 필요하다고 하였다.59) 총 독부는 1920년대 중반 이후 조선의 청년단체를 어용단체로 만들기 위해 국고와 지방비를 지원하기 시작하였다. 각 지방의 청년단은 관변 청년단체의 성격을 가지고 활동하였다. 만 주침략을 계기로 총독부는 청년단을 전쟁동원의 대중적 기반확보의 주요거점으로 삼았다. 조선청년에 대한 선도의 필요성은 이전의 데라우치 총독시대에 무단통치가 조선 청년의 반 감을 양성하여 '소요'사건이 일어났음을 강조하면서 제기되었다. 역대 총독이 조선 청년사상 에 대해 무시하고 있는 것이 유감이라며 이제는 이들을 등용하여 조선 통치에 참여시키는 포용주의로 선도해야 한다고 말한다.60) 청년 사상의 선도에 대해 豊島佐太郎(『조선공론』 편

54) 賀田直治,「朝鮮産業と敎育の協調」『朝鮮公論』10권 1호, 1922.1, 12 4쪽.

55) 本誌記者,「队鮮融和の根本的解決, 『朝鮮公論』12권 6호, 1924.6, 55 56쪽.

56) 石森久彌,「朝鮮と農村問題-朝鮮青年に歸農を勸む」『朝鮮公論』11권 6호, 1923.6,

57) 石森久彌,「朝鮮産業と敎育との均齊」『朝鮮公論』14권 6호, 1926.6, 2 5叒.

58) 河野節夫, 「朝鮮に於ける民心先導と其機關」『朝鮮公論』9권 8호, 1921.8, 37 47쪽.

59) 河野節夫, 「朝鮮に於ける文化の趨勢と其指標, 『朝鮮公論』9권 11호, 1921.11, 36 37丝. 
집부장)은 청년단의 조직 결성을 통해 해결하는 것이 급무라고 촉구하였다. 총독부에 사회 과가 있어서 사회문제에 관한 연구를 하고 있지만 대부분 노인계급에만 중점을 두고 청소년 의 사상문제에 대해서는 보통학교나 고등보통학교의 교육기관을 기다리는 것이 많다고 했 다. 근본문제는 '사상 상의 선도 즉 선정'이 아니면 안 된다. 그러나 시골에 있는 청년의 유 도에 대해서는 아무런 방법도 강구하고 있지 않은 것이 문제라고 지적하고 있다.61)

金心石은 총독부의 시정이 일시동인에 따라 모든 면에서 민족의 차별을 두지 않고 융화에 노력했지만 '물과 기름'을 합체하려고 해도 본질이 다르다. 그러므로 조선민족은 정신부터 고쳐야 한다고 보았다. 내선인의 행동은 서로 일치할 수가 없기 때문에 서로 사상을 달리하 고, 표면적으로 조선통치가 평정으로 돌아간다고 해도 이면에는 위험한 사상이 조류하고 있 는 것은 민족적 요구라고 보았다. 이러한 민족정신을 수단과 방법을 가리지 않고 박멸하는 것은 불가능하다고 이해하여 조선 민족의 요구와 민족운동의 위험성을 지적하고 있다.62) 이시모리도 조선 민족성에 대한 고찰이 필요함을 지적하고 있다. 그는 대진재 당시의 일본 인의 추태는 일본민족의 감정이 격발하여 일어난 부끄러운 일이라고 인식하였다. 당시 경시 총감이 조선민족의 성정을 자세하게 연구했다면 이 정도 낭패스러운 일이 일어나지 않았을 것이라고 말한다. 그는 “조선민족과의 정신적 결합, 그것은 同種同民論이나 내선융화론으로 는 절대로 불가능하다. 상호의 민족정신 및 민족성을 연구하여 그 이해, 아량, 협동에 의해 비로소 얻을 수 있는 것”이라고 민족성 연구의 중요성을 강조하였다.63) 이러한 조선인의 민 족성을 이해하여 그들을 교화시키는 것은 조선인에게 일본의 무사도 정신을 보급하여 내선 의 정신적 연계를 도모하고 동시에 동아의 맹주로 국책 수립에 나가는 길이라고 보았다.64) 金義用(동민회 평의원)은 조선인의 사상경향을 연구하여 조선인들이 민족운동에 매진하는 이유를 한일합병의 사실을 부인하는데서 찾았다. 그러나 합병 사실을 부인하는 것은 '시대 착오이고 대세역행'이라고 비판한다. 그는 (1) 조선만의 국가적 독립은 불가능하다, (2) 동문 동종의 두 소국가가 병합한 이상 하나의 대국가로 국제간에 존재하는 것이 현명하다. 분립 하는 것은 양 민족에게 불이익이다, (3)일한병합은 세계에 자랑할 만한 역사적 사실이라고 말하면서, 조선에서 사상통치 문제를 연구해 보았지만 최대 난관에 봉착한 것은 내선융화의 실현문제라고 언급하였다.65)

후쿠모토(福本貞義)는 조선 청년의 대부분은 “독립병의 보균자”이며, 교육의 보급이 민족사 상을 배양하고 동민회, 국민협회, 상애회의 융화운동은 조선인의 반감을 샀다고 말한다. 그 는 “지식의 계발은 일본에 동화되기보다 도리어 부지불식간에 조국회복의 사상을 배양하였 다. 그 원인은 교육방침의 잘못에 있다. 특히 역사교육의 무방침에 기인한다.”고 평했다. 그 러면서 내선융화의 근본원리로 “내선인이 함께 반드시 취해야 할 표적을 명시하지 않으면 안 된다. 그것은 일본건국의 대정신, 일본 황실의 신성 및 일본신민의 대사명을 밝히는 것, 한마디로 일본은 어떠한 나라인가를 이해시키는 것에 의해 달성할 수 있다.”고 주장하였 다.66)

이상에서 살펴본 것처럼 문화정치기의 통치방식은 무단통치기와 비교하여 본질에서는 전혀

60) 사설,「朝鮮靑年を善導せよ」,『朝鮮公論』10권 4호, 1922.4, 5 쪽.

61) 豊島佐太郎,「近代思想の先導と朝鮮靑年團創設-劃一的靑年團の組織と慣䀜打破, 『朝鮮公論』11권 9호, 1923.9, 41 47叒.

62) 金心石, 「朝鮮民族的の要求運動考察」『朝鮮公論』11권 5호, 1923.5, 78쪽.

63) 石森久彌, 「朝鮮民族性に對寸る考察」『朝鮮公論』13권 8호, 1925.8, 2 9쪽.

64) 石森久彌, 「朝鮮民族の敎化と武道精神, 『朝鮮公論』14권 3호, 1926.3,3 4 4쪽.

65 ) 金義用,「朝鮮思想統治の一考察,『朝鮮公論』17권 8호, 1929.8, 44 53쪽.

66) 福本貞義,「队鮮融和の根本原理」『朝鮮公論』17권 8호, 1929.8, 103 106쪽. 
다르지 않고 교묘하게 강화된 것이다. '내선융화'를 내걸고 동시에 조선인을 회유하는데 우 선 조선 청년을 사상적으로 선도하고 조선인의 민족성을 연구하는데 중점을 두어야 한다는 주장이 나왔다. 구체적인 방안으로는 조선인의 역사·국어·수신 교육과 공학 교육, 청년단 설립과 조선인물 양성이 필요하다는 지적이다.

\section{2. 내선융화의 방법}

정무총감 미즈노 렌타로는「內鮮兩民族の眞使命」(1921.8)에서 조선은 항상 고립되어 국가를 유지하는 것이 곤란한 일이었고, 조선민족의 생명과 재산은 끊임없이 위협당하고 있었다고 말한다. 이 화란을 없애는 유일한 방법은 日韓이 일체가 되는 외에 방법이 없다고 보았다. 이 정신을 관철하기 위해서는 "내선인 사이에 있는 민족적 편견을 없애고 그 사이의 장벽을 제거하여 상호 대일본제국 신민으로 세계를 향한 포부와 이상을 가져야 한다.”고 지적하여 이른바 '일시동인'의 정신이 여기에 존재한다고 강조하였다. 이하에서 내선 경제동화, 우량 인물 양성, 내선 사상동화, 재조선 일본인의 각성 문제를 중심으로 살펴보자.

첫째, 경제적 방면의 동화 문제에 대해서 하야시다 가메타로(林田龜太郎, 중의원 의원)와 이 스미 추조(亥角仲藏, 전북도지사)의 주장을 보자. 먼저 하야시다는 정치 방면에서의 동화보 다 경제 방면에서 동화, 융합시키는 것이 묘미가 있다고 본다. 3,4 백 만 명의 일본인을 조선 에 보내면 국고 2-3천만 엔이 절약되며 조선에서 모국으로 미곡 등을 보내 지방의 개발, 문 화의 기여자로서 움직일 수 있게 된다. 그는 구체적으로 한 도마다 큰 이민회사를 두고 사장 은 구 다이묘(大名) 가운데 13 명을 선발해서 폐하의 칙명 아래 그 임무를 맡기자고 한다. 그 러면 그들은 봉공의 정신을 가지고 조선에 건너가 개간에 종사하여 13 도에 걸쳐 대이민이 분 포되어 국가는 한 푼을 쓰지 않고 훌륭한 통치기반을 만들 수 있다고 제안하였다.67) 다음 이 스미는 병합의 본의에 따라 내선합체로 국운의 융창을 도모하는 것은 급무이다. 내선공영을 신조로 조선의 산업개발을 도모하기 위해 내선 경제적 결합은 긴요하다고 말한다. 그러나 산업은 결국 사람이 움직이는 문제이므로 인적 요소가 중요하며, 각 사람이 和衷 협조의 정 신과 진취적인 마음을 가지고 노력하는 것이 산업진흥의 근원이 된다고 보았다. ${ }^{68)}$

둘째, 우량인물의 양성이 필요하다. 韓相龍(한성은행 두취)은 조선개발의 촉진은 관민이 일 치 협력하여 각종 유리부원을 개척하고 풍요로운 물자의 산출을 도모하는 것인데, 이 보다 더 필요한 일은 조선인 가운데 우량인물을 배출하는 것이라고 말한다. 이러한 인물양성은 교육의 힘을 기다려야 하며 교육기관만이 아니라 사회적 교육을 통해 내선융합의 실적을 거 둘 수 있는 것이라고 주장하였다. 즉 조선을 개척하는 것은 물자가 아니고 풍부한 인물이 아니면 안 된다고 하여 교육의 중요성을 역설하였다.69) 학무국장 주앷ㅇㅁㅁㄷㅗ 내선융합의 실적 을 올릴 수 있는 길은 초등교육의 보급발달에 있음을 강조하였다. “나는 초등교육의 확장을 첫째로 하고 싶다. 조선에는 아직 의무교육 제도는 실시되고 있지 않다. 이 제도가 없으므 로 다수의 자제를 無學으로 끝내게 하는 것은 결코 좋지 않다. 진정으로 내선융화의 실을 올리는 것은 장차 조선 사람들로 하여금 진정 제국의 국민이 될 자질과 자각을 얻게 하는 것이다"70), 이를 위해서는 무엇보다 초등교육의 보급발달을 급무로 하지 않으면 안 된다고 보았다.

67) 林田龜太郎,「經濟的方面の同化策」『朝鮮公論』8권 11호, 1920.11, 37 38 쪽.

68) 亥角仲藏,「內鮮經濟的結合」『朝鮮公論』11권 4호, 1923.4,37丝.

69) 韓相龍, 「鮮産人物養成論, 『朝鮮公論』15권 11호, 1927.11, 9 10驽.

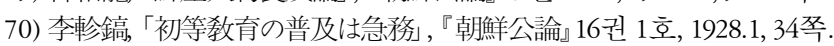


셋째, 내선 동화의 방법은 차별을 철폐하는 것이라고 보는 金井泉(김심석)과 豊島佐太郎(편 집부장), 하야시(林省三, 洗足團)의 견해가 있다. 金井은 조선인은 특수 법규보다 일반적인 법규를 바란다고 말한다. 보안법, 제령위반 벌칙, 출판물취체규칙 등은 차별법규이므로 내선 공통의 치안법 아래에서 과격주의 사상자를 취체하는 것이 일시동인의 취지라고 보았다. 그 는 조선민족의 결점에 대해 (1) 정신부터 고치지 않으면 진정한 동화는 바랄 수 없다, (2) 성 급하고 희노애락이 빠르다, (3) 사람에게 아첨하는 풍조가 있다, (4) 초조해 하는 풍조가 있 다, (5) 너무 외형을 숭상한다. 이러한 결점이 조선인을 경멸하게 하는 원인이 되므로 내선 융화상 대결점이며 이에 대한 반성을 촉구하였다. 그는 내지인이 조선인에게 친절하게 한다

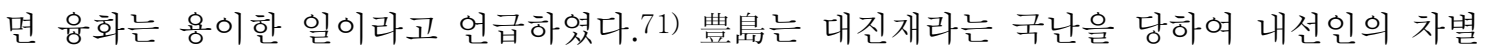
없이 정신적 귀일 결합이 필요하다고 보았다. 관민이 일치해서 화를 복으로 바꿀 각오를 가 지고 국가의 기초를 만들려고 노력하지 않으면 안 된다.72) 하야시는 조선민족의 문화적 육 성은 일본이 아세아의 패자가 되는 제일보이며 제국의 사명이라고 말한다. 그러나 이 사명 을 수행해야 할 일본인이 조선인을 경멸하고 모욕하며 차별적인 태도로 나오고 있다고 비판 한다. 진정한 일본정신으로 돌아가지 않으면 학대받은 조선민족이 파멸에 빠지고 제국이 불 리하게 되는 일이라고 지적하고 내지인의 각성을 촉구하였다.73)

넷째, 재조선 내지인의 개조와 각성이 필요하다. 인적요소의 중요성 지적은 쪼⿱ 랄ㄴㄴㅇㅢ 모국 인의 조선에 대한 무관심, 무이해에 대한 문제 제기에서도 나타난다. 그는 모국인은 물론 재조선 내지인조차 조선에 냉담한 것은 '일선융화, 내선동화'라는 말의 진정 의미하는 바가 어디에 있는지 알 수 없게 만든다고 말한다. 아울러 조선 문화의 수준이 낮지만 조선 청년 의 사상은 재조선 내지인 청년에 비해 우수하다는 지적을 통해 내지인의 각성을 촉구하였 다.74) 히로세(廣瀨操)는 내선융화가 되지 않는 원인은 강자인 내지인이 약자인 조선인에게 불손과 전횡으로 대하기 때문이다. (1) 출신지 자랑이 강한 일본지상주의자가 조선인을 무시 한다. (2) 내지인의 불손, 오만무례한 태도가 있다. (3) 내지인이 가진 식민지 근성의 개조가 필요하다. (4) 동척의 무분별한 이민모집 방법이 내선융화의 실적을 올리지 못하게 한다.75) 수은 일선융화를 위해 노력하는 사람이 적은 현실에 놀랄 수밖에 없다고 말한다. 그는 일 본인은 왜 조선인을 그렇게 열등시하느냐고 묻는다. 모멸당하는 조선인은 이제 '바보'가 되 었고 “이 바보가 된 머리에서는 문화정치가 무엇인지도 모르고 그 고마움도 모르기 때문에 아무리해도 그 문화정치로 가는 것이 불가능할 것이라고 생각합니다. 만약 문화정치를 시행 하려고 생각한다면 일선융화라는 것부터 먼저 하지 않으면 안 됩니다.”라고 하였다. 그는 일선융화를 실현시키기 위해서는 조선인을 이해하지 않으면 안 된다고 하여 '외피만의 문화 정치'는 실패할 것이라고 단언하고 있다.76) 카스야 기조(粕谷義三, 중의원 의장)는 양 민족 의 융합은 양자가 충심으로 이해하여 성격의 이해, 감정의 융화가 가능하게 되면 결코 어려 운 일이 아니라고 말한다. 그러나 일본인 중에는 조선에 대한 지식이 없이 마음대로 말하고 있는 결점이 있다고 한다. 조선인 측에서도 일본인에 대한 편견을 가지고 재조선 일본인을 보고 전체 일본인을 악덕자라고 생각하는 문제가 있다고 지적하였다. 융합이란 것은 서로가 성의를 표시할 때 악수할 수 있다는 것이다. ${ }^{77)}$ 재조선 유식계급의 책임에 대한 지적은 젠쇼

71) 金井泉, 「队鮮同化策と吾人の主張, 『朝鮮公論』11권 9호, 1923.9, 62 66쪽.

72) 豊島佐太郎, 「國難來と吾人の覺悟=精种的に內鮮人結合の時機,『朝鮮公論』11권 10호, 1923. 10, 81超.

73) 林省三、朝鮮問題につき吾か內內地人に檄す」『朝鮮公論』12권 6호, 1924.6, 57〜 58쪽.

74) 翠郎生,「內鮮協調偶感,『朝鮮公論』11권 5호, 1923.5, 84 86丝.

75) 廣瀨操, 「在鮮內地人の質的改造を提唱す」, 『朝鮮公論』12권 6호, 1924.6, 44 47 쪽.

76) 金一, 「在鮮队地人の反省を促す」, 『朝鮮公論』12권 11호, 1924.11, 84 85丝. 
에이스케(善生永助)에게도 보인다. 그는 이들이 야비하고 교양없는 언동으로 내선융화를 방 해하고 있어 국가의 장래에 큰 손실을 양성하고 있다고 말한다. 조선통치의 공죄는 정부 당 국자에게만 돌아가는 것이 아니라 이들의 책임이고, “감정이 융화하지 않으면 조선 통치는 실패로 끝난다"는 인식이다.78)

다섯째, 내선융합의 방법은 무엇일까. (1) 혼다 코조(本田恒三)는 일선동조회의 설립을 제창 하여 조선인의 일반 사상계가 융화되기를 바란다.79) (2) 곤도(近藤常向, 총독부 도서과장)는 동조동문의 양 민족의 융합을 촉진하기 위해 내지의 도서를 도입하여 인정, 풍속을 알게 한 다.80) (3) 俞星濬(강원도지사)은 강원도에는 내선 동조동문을 입증해줄 素盛鳴尊 유적이 있 다. 조선통치상 중대한 지역으로 충분한 가치가 있게 만든다.81) (4) 노세 이와키치(能勢岩吉) 는 조선인의 생활을 향상시키고 생활정도를 내지인과 가깝게 개조해야 한다82)는 의견들이 나왔다.

이상에서 어떻게 해야 내선융화를 이룰 수 있을까에 대해서 제기된 것은 일본인 이주를 장 려하여 경제동화를 달성하고 통치기반을 조성해야 한다. 그리고 조선인 가운데 우량인물을 양성하고 초등교육을 보급하여 내선융화의 실적을 올린다. 조선민족에 대한 차별을 철폐하 고 재조선 일본인의 개조와 각성을 촉구해야 한다고 보았다. 이를 통해 조선인의 사상계가 융화되고 조선인에게 일본의 인정과 풍속이 더 많이 알려져 일본에 대한 이해를 높일 것을 강조하였다.

\section{IV. 맺음말}

본 논문에서는 재조일본인이 경영하는 『조선공론』의 사설에서 1920 년대의 식민지 조선을 어떻게 인식했으며 일본의 지식인들이 조선 문제에 대해 어떠한 주장을 펼쳤는지 살펴보았 다.

1910년대의 『조선공론』 사설에서는 무단통치를 비판하고 무관총독 폐지문제를 거론하였다. 조선 통치를 위해서는 조선인 동화가 중요하며 그것은 일본인 이주와 조선인 사상연구, 내 선인 결혼, 조선인 개명, 일본어 보급 등을 통해 정신적 동화가 필요하다는 주장이었다.

1920 년대는 $3 \cdot 1$ 운동을 격은 일제가 1910년대의 동화정책 전략을 문화통치로 바꾼 시기이 다. 동화정책을 유지하면서도 이를 점진적으로 실행하고 차별대우를 완화하려는 것이었다. 그리하여 1920년대에 들어 '동화'라는 말 대신에 '융화'라는 말이 채용되었다. 1920년대『 조선공론』의 사설에서는 1910년대의 논조와 비교해 보면 다음과 같이 무단통치에 대한 비 판과 옹호, 군비축소 여부에 대한 논란이 이어지고 '내선융화' 문제가 본격적으로 거론되었 다.

데라우치 총독의 무단통치 평가에 대해 헌병제도 폐지, $3 \cdot 1$ 운동에 대한 대응책의 하나로 제기된 군비축소 문제, 병비충실운동을 중심으로 살펴보았다. 무단통치에 대한 비판과 함께 문관 총독이 필요한 시대가 되었다는 견해와 총독 정년제가 필요하다는 주장도 제기되었다. 한편 조선인에게 참정권을 부여하는 문제는 총독부의 공식적 입장인 내지연장주의론과 일본

77) 粕谷義三, 「队鮮民族の融合」、『朝鮮公論』14권 5호, 1926.5, 18 쪽.

78) 善生永助,「朝鮮統治と有識階級の責任」『朝鮮公論』14권 11호, 1926.11, 17 20驽.

79) 本田恒三, 「日鮮同祖會設立の提唱-日鮮融合の根本義, 『朝鮮公論』14권 1호, 1926.1, 58 62쪽.

80) 近藤常向,「內鮮融和と小說, 『朝鮮公論』15권 1호, 1927.1, 64 65叒.

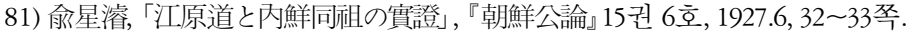

82) 能勢岩吉, 「內鮮融合と朝鮮人の生活,『朝鮮公論』15권 6호, 1927.6, 2 12叒. 


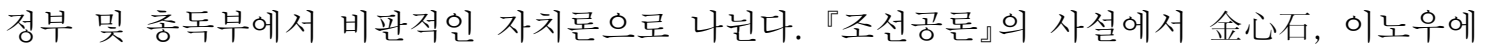
등은 참정권을 부여해야 한다고 말했지만 미야자키는 그것은 이상론에 불과하며 중추원 개선 이 필요하다고 보았다. 이시모리도 내지연장주의에서 '조국연장주의'로 나갈 것을 주장하였다. 문화정치기의 통치방식은 무단통치기와 비교하면 본질에서는 전혀 다르지 않고 교묘하게 강 화된 것이다. '내선융화'를 내걸고 조선인을 회유하기 위해서는 우선 조선 청년을 사상적으 로 선도하고 조선인의 민족성을 연구하는데 중점을 두어야 한다는 주장이다. 구체적인 방안 으로는 조선인의 역사·국어·수신 교육과 공학 교육, 청년단 설립과 조선인물 양성이 필요 하다고 보았다. '내선융화'의 방법으로 일본인 이주를 장려하여 경제동화를 달성하고 통치기 반을 조성하고, 조선인 우량인물의 양성과 초등교육의 보급을 통해 '내선융화'의 실적을 올 릴 것을 강조한다. 조선민족에 대한 차별을 철폐하고 재조선 일본인의 개조와 각성을 촉구 하였다. 1930년대에는 이러한 논조가 어떻게 변화되는지에 대해서는 별고에서 다루어 보려 고 한다.

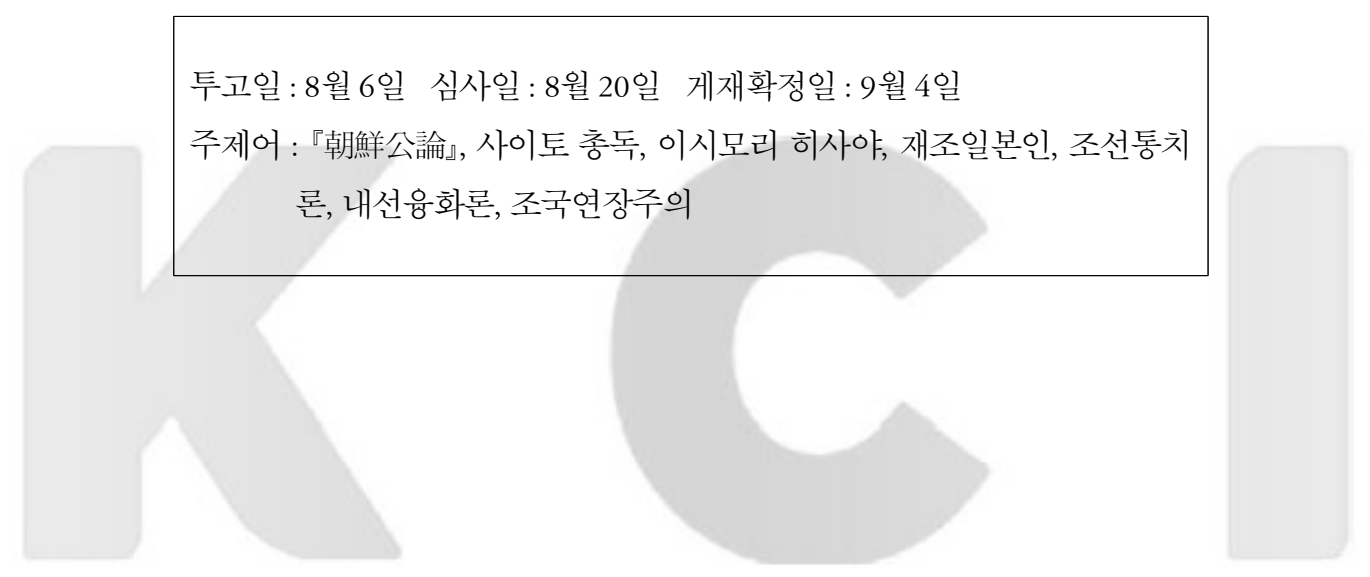


- 참고문헌

『朝鮮及滿洲』, 『朝鮮公論』

기유정,「식민지 조선에 대한 척식성 지배 논란과 그 함의」, 『정치사상연구』19-1, 2013 봄.

김종식, 「1910년대 재조일본인 정치가의 정체성 형성과정」『사림』56, 2016.

김청균, 「일본어잡지『朝鮮公論』(1913-1920)의 에세이와 한국인식」, 『한림일본학』18, 한림대 일본학연구 소, 2011.

박양신, 「사학 와세다 인맥을 통해 본 일본 - 식민지 조선에서의 식민정책론」, ${ }^{『}$ 아시아문화연구』39, 2015. 山本有造,「日本における植民地統治思想の展開」,『アジア經濟』32-2, 1991,

송미정,『朝鮮公論』소재 문학적 텍스트에 관한 연구-재조일본인 및 조선인 작가의 일본어 소설을 중심으 로」, 국민대학교 박사논문, 2009.

조은애, 「1920년대 초반『朝鮮公論』문예란의 재편과 식민의 “조선문단” 구상」, 『일본사상』19, 2010. 최혜주,「잡지『朝鮮及滿洲』에 나타난 조선통치론과 만주인식」, 『한국민족운동사연구』62, 2010.

최혜주, 「잡지『朝鮮公論』의 1910년대 사설에 나타난 조선통치론」『한국민족운동사연구』89, 2016.
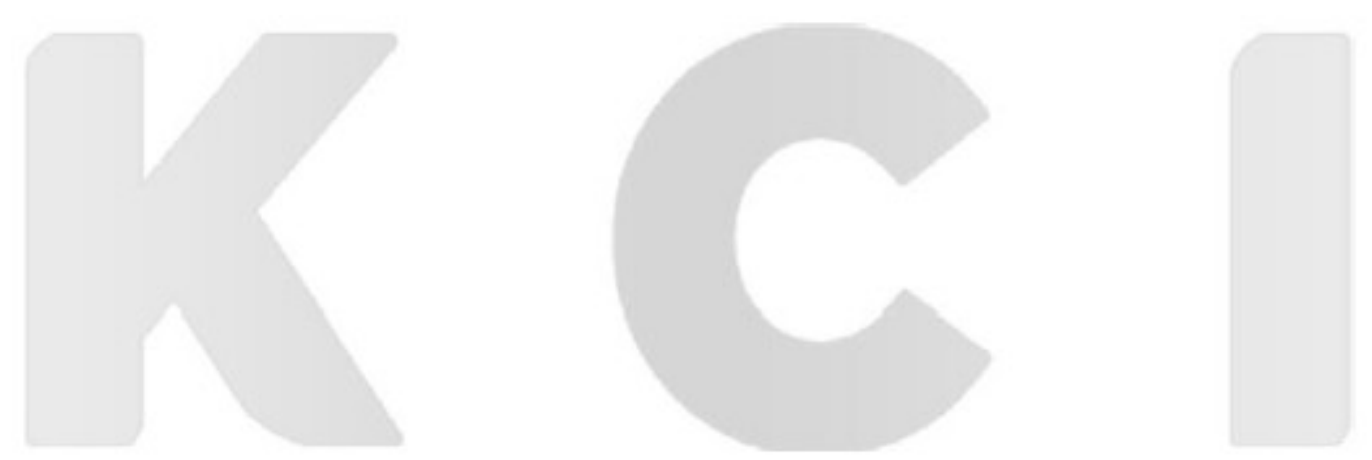
- 국문요약

\section{0년대의『朝鮮公論』사설에 나타난 조선통치론과 내선융화론}

최혜주

『朝鮮公論』은 마키야마 고조(牧山耕藏)가 1913년 4월 창간한 이래 1944년 11월까지 총 380호를 발행한 최장수 월간 종합잡지다. 이 잡지에는 일본의 정관계, 언론계, 교육계, 법조 계, 경제계 등 지식인들의 담론이 담겨있다. 이들은 조선통치정책에 일정하게 영향을 미쳤 던 정치세력들이었다. 이 잡지의 1910년대 사설에서는 무단통치를 비판하고 무관총독 폐지 문제를 거론하였다. 조선 통치를 위해서는 조선인 동화가 중요하며 그것은 일본인 이주와 조선인 사상연구, 내선인 결혼, 조선인 릴ㅇㅁ, 일본어 보급 등을 통해 정신적 동화가 필요하 다는 주장이었다.

1920년대는 $3 \cdot 1$ 운동을 격은 일제가 1910년대 동화정책의 전략을 문화통치로 바꾼 시기이 다. 동화정책을 유지하면서도 이를 점진적으로 실행하고 차별대우를 완화하려는 것이었다. 그리하여 1920년대에 들어 '동화'라는 말 대신에 '융화'라는 말이 채용되었다. 이 논문에서 는 『조선공론』의 사설에서 1920년대의 식민지 조선을 어떻게 인식했으며 일본의 지식인들 이 조선 문제에 대해 어떠한 주장을 펼쳤는지 조선통치론과 내선융화론을 중심으로 살펴보 았다. 1910년대의 논조와 비교해 보면 무단통치에 대한 비판과 옹호가 계속되고 있으며 군 비축소 여부에 대한 논란이 이어지고 ‘내선융화' 문제가 본격적으로 거론되었다.

데라우치 무단통치의 가장 큰 문제는 헌병제도였다. $3 \cdot 1$ 운동에 대한 대응책의 하나로 제기 된 군비축소 문제에 대한 논란과 함께 헌병제도 폐지를 둘러싸고 다양한 논의가 나왔다. 문 관 총독이 필요한 시대가 되었다는 견해와 총독 정년제가 필요하다는 주장도 제기되었다. 한편 조선인에게 참정권을 부여하는 문제가 논란이 되었다. 소임, 이노우에 등은 참정권 을 부여해야 한다고 말했지만 미야자키는 그것은 이상론에 불과하며 중추원 개선이 필요하 다고 보았다. 이시모리도 내지연장주의에서 ‘조국연장주의’로 나갈 것을 주장하였다.

'내선융화'를 내걸고 조선인을 회유하기 위해서는 우선 조선 청년을 사상적으로 선도하고 조선인의 민족성을 연구하는데 중점을 두어야 한다는 주장이다. 구체적인 방안으로는 조선 인의 역사·국어·수신 교육과 공학 교육, 청년단 설립과 조선인물 양성이 필요하다고 보았 다. '내선융화'의 방법으로 일본인 이주를 장려하여 경제동화를 달성하고 통치기반을 조성해 야 한다. 그리고 조선인 가운데 우량인물을 양성하고 초등교육을 보급하여 '내선융화'의 실 적을 올릴 것을 강조한다. 조선민족에 대한 차별을 철폐하고 재조선 일본인의 개조와 각성 을 촉구하였다. 
- Abstract

Rule over Chosun and Japan-Chosun Conciliation Found in the Editorials of ${ }^{\circledR}$ Chosun Gongron $₫$ in the 1920's

Choi, Hea-joo

${ }^{\circledR}$ Chosun Gongron』 was monthly general magazine lasting the longest with total 380 issues from April, 1913 when Makiyama Gojo (牧山耕藏) began the first issue up to November, 1944. This magazine included discourses from Japanese intellects in the areas of politics, journalism, education, law, and also economy. They formed political power that constantly exerted influence on Japan's policy of ruling Chosun then. The magazine's editorials in the 1910's criticized forceful ruling and discussed the matter of abolishing the rule of military officers as governors. They insisted that to govern Chosun properly, Chosun people's assimilation would be crucial, and their mental assimilation would be essential through Japanese's immigration, research on Chosun people's thinking system, marriage between Japanese and Chosun people, Chosun people's renaming, and also distribution of Japanese.

The 1920's was the period that the Japanese Empire that had faced the $3 \cdot 1$ Independence Movement altered their strategies of assimilation policy in the 1910's into cultural ruling. While maintaining assimilation policy, they enforced it gradually as well and reduced discriminative treatment. In fact, in the 1920's, instead of the term, 'assimilation', they used the word of 'conciliation'. This study aims to examine how they recognized the colony, Chosun, in the 1920's with the editorials of $『$ Chosun Gongron』 and look into what opinions Japanese intellects presented about the matters of Chosun through their theory of ruling Chosun and Japan-Chosun conciliation. Comparing the editorials of the 1910's and 1920's, this author has found that they kept criticizing and advocating forceful ruling, there were controversies about reducing arms, and they genuinely discussed the matter of 'Japan-Chosun conciliation'.

The biggest problem of Derauchi's forceful ruling was the system of military police. Along with disputes about the issue of reducing arms as one of the measures to cope with the $3 \cdot 1$ Independence Movement, they presented various opinions around the matter of abolishing the system of military police. They insisted on the necessity of civil servants as governors and also supported the necessity of the age-limit system for governors. Meanwhile, it was also a controversy to provide Chosun people with their legitimate government. Kim Sim-seok or Inoue insisted on the necessity of their legitimate government whereas Miyajaki said it was just the 
ideal theory and Jungchuwon was needed to be reformed. Ishimori, too, said they should go with 'Joguk Yeonjangjuui' from 'Naeji Yeonjangjuui'.

It means that to conciliate Chosun people through 'Japan-Chosun conciliation', first, it would be needed to lead Chosun's youths ideologically and focus more on studying Chosun people's racial characteristics. To put it concretely, it would be necessary to provide Chosun people with education for history, language, cultivation, and engineering, found youth organizations, and cultivate Chosun's figures. It would be also needed to encourage Japanese's immigration through 'Japan-Chosun conciliation' and attain economic assimilation and lay the grounds for ruling. In addition to that, it would be needed to cultivate superior figures from Chosun people and distribute elementary education in order to accomplish 'Japan-Chosun conciliation' indeed. It would be also necessary to get rid of discrimination on Chosun people and urge Japanese residing in Chosun to change and wake up.

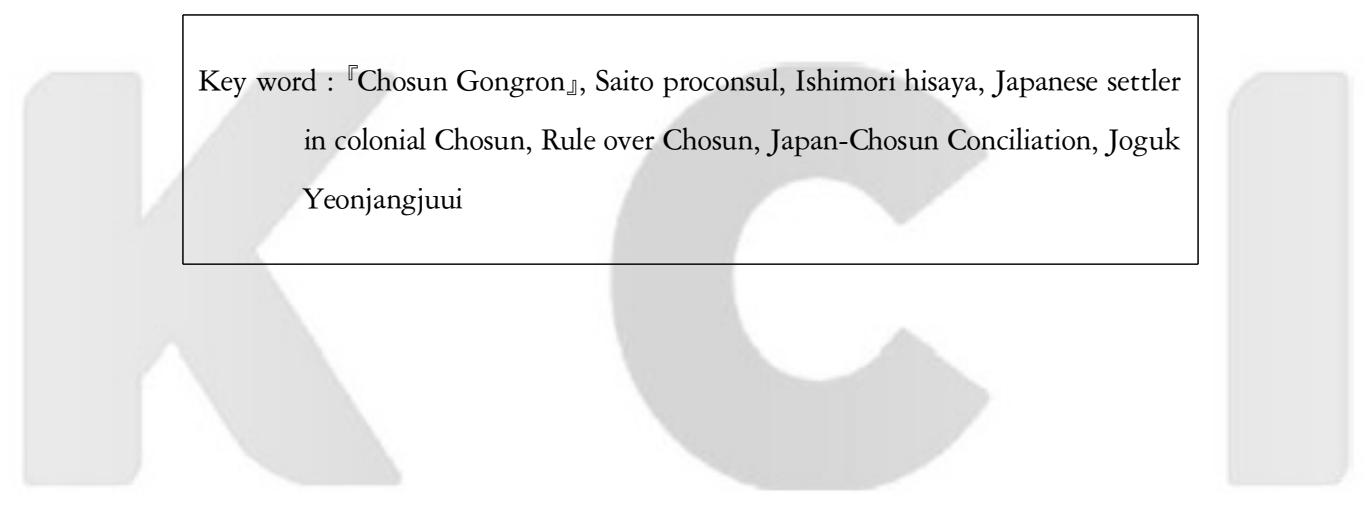

